\title{
Determination of genome size of Pseudomonas aeruginosa by PFGE: analysis of restriction fragments
}

\author{
Janel S.R.Hector and Alice R.Johnson \\ Department of Biochemistry, Research Building, University of Texas Health Center at Tyler, Tyler, \\ TX 75710, USA
}

Received March 20, 1990; Revised and Accepted April 9, 1990

\begin{abstract}
Genomic DNA size was measured in three strains of Pseudomonas aeruginosa, ATCC 29260 (exotoxin A), ATCC 33467 (type I smooth) and ATCC 33468 (type 2 mucoid) by transverse alternating field electrophoresis of restriction fragments. Because of the high $(67 \%)$ G + C content of Pseudomonas aeruginosa, restriction enzymes that recognize sequences with at least 4 AT base pairs were expected to be rare cutters. Eight enzymes produced fragments greater than $200 \mathbf{~ k b}$ in size: Dral (TTT/AAA), Asnl (ATT/AAT), Hpal (GTT/AAC), Aflll (C/TTAAG), Xbal (T/CTAGA), Spel (ACTAGT), Sspl (AAT/ATT) and Ndel (CA/TATG). All eight enzymes recognized one of three rare tetranucleotide sequences, TTAA, CTAG or ATAT. Pseudomonas aeruginosa strain 29260 has a genomic DNA size of $5573 \mathrm{~kb}$. Strains 33467 and 33468 have identical restriction patterns and a possible deletion with a genomic size of $5407 \mathrm{~kb}$.
\end{abstract}

\section{INTRODUCTION}

The recent development of pulsed field gel electrophoresis (PFGE) (1-4) provides the means to separate large DNA fragments and whole chromosomes up to $10,000 \mathrm{~kb}$ in size $(5-8)$. Whole chromosomes from Saccharomyces cerevisiae and $S$. pombe are readily separated by transverse alternating field electrophoresis (TAFE). Chromosome sizes vary from 200-1140 kb for $S$. cerevisiae (9) and 3000-9000 kb for $S$. pombe (10). Human chromosomes are significantly larger, ranging from $50,000 \mathrm{~kb}$ (chromosome 21) to $250,000 \mathrm{~kb}$ (chromosome 1), and have not yet been separated successfully by alternating current electrophoresis systems (11). However, this technique, combined with restriction analysis (12), has been applied successfully to estimate sizes of circular bacterial chromosomes from E. coli (13), Mycoplasma mycoides (14) and Haemophilus influenzae (15-17).

We report here the genomic DNA size of three Pseudomonas aeruginosa strains determined with PFGE and report significant differences in restriction fragment sizes in one of the strains.

\section{METHODS}

Pulsed field gel electrophoresis

Bacterial DNA was separated in a GeneLine TAFE system (Beckman) developed by Gardiner (18). Gels were made of $1 \%$ low endoosmosis (LE) agarose (Beckman) and run at $12^{\circ} \mathrm{C}, 150$ $\mathrm{mA}$, constant current, in TAE buffer $(0.01 \mathrm{M}$ Tris, $0.0001 \mathrm{M}$ EDTA, 0.00435M acetic acid). Pulses from 1 to 60 seconds were applied over $15-18 \mathrm{hr}$ to separate $2-1600 \mathrm{~kb}$ DNA fragments. The gels were stained with ethidium bromide and photographed using an ultraviolet transilluminator (Spectroline, $302 \mathrm{~nm}$ ).

\section{DNA standards}

Four DNA standards were used. S. cerevisiae plugs (9) and lambda concatemers (43.7 and $48.5 \mathrm{~kb}$ monomer) were purchased from Beckman. High molecular weight DNA standards from $50 \mu \mathrm{g}$ lambda restriction digests (BRL) were incubated at $65^{\circ} \mathrm{C}$ for 10 minutes to minimize spontaneous annealing at cos sites, then mixed with $1.2 \mathrm{ml} 1 \%$ LMP agarose and molded into plugs. Lambda HindIII digests (500 $\mu \mathrm{g}$ Sigma) were suspended in a mixture of $1.5 \mathrm{ml}$ TE buffer and $1.5 \mathrm{ml} 1 \%$ LMP agarose and molded into plugs. All plugs were stored at $4{ }^{\circ} \mathrm{C}$ in TE buffer.

\section{Pseudomonas strains}

Pseudomonas aeruginosa strains ATCC 29260, 33467 and 33468 were chosen for restriction fragment analysis. Strain 33467 is smooth and strain 33468 is mucoid, but both lack indophenol oxidase usually found in Pseudomonas (19). Strain 29260 (PA-103) is a poor producer of proteases, but produces large amounts of exotoxin A (20). The bacteria were grown overnight at $37^{\circ} \mathrm{C}$ in $10 \mathrm{ml}$ trypticase soy (TCS) broth with shaking, suspended in $2.0 \mathrm{ml}$ TE buffer, mixed with an equal volume of $1 \%$ LMP agarose in lysis buffer and poured into plug molds. Plugs were shaken overnight at $37^{\circ} \mathrm{C}$ in $5 \mathrm{ml}$ TE buffer containing $1 \mathrm{M} \mathrm{NaCl}$ and $1 \mathrm{mg} / \mathrm{ml}$ lysozyme to lyse the cells. A second incubation was performed at $50^{\circ} \mathrm{C}$ for 48 hours in $5 \mathrm{ml} \mathrm{TE}$ buffer containing $1 \%$ SDS and $1 \mathrm{mg} / \mathrm{ml}$ proteinase $\mathrm{K}$. Plugs were then incubated overnight at room temperature, in TE buffer with 10 $\mathrm{mg} / \mathrm{ml}$ PMSF. The plugs were washed four times in TE buffer for 12 hours and stored at $4{ }^{\circ} \mathrm{C}$ until used.

\section{Restriction enzymes}

Restriction enzymes, selected for their specific cleavage sites, were purchased from commercial sources and used according to the recommendations of the manufacturer. Pseudomonas plugs were incubated overnight in $60 \mu \mathrm{l}$ of restriction buffer with $1-2$ $\mu \mathrm{l}$ of the selected enzyme (21). All materials and utensils were autoclaved or washed in alcohol to eliminate contaminating 
Table 1. Restriction enzymes, restriction sequence and largest restriction fragment resulting after Pseudomonas 33468 digestion. (Key: $\mathrm{A}=$ adenosine, $\mathrm{C}=$ cytosine, $\mathbf{G}=$ guanine, $\mathrm{T}=$ thymidine, $\mathrm{U}=$ purine, $\mathrm{Y}=$ pyrimidine, $\mathrm{N}=$ nucleotide)

\begin{tabular}{|c|c|c|}
\hline $\begin{array}{l}\text { All Fragments } \\
<2 \mathrm{~kb} \text { in size } \\
>3000 \text { fragments }\end{array}$ & $\begin{array}{l}\text { All Fragments } \\
<60 \mathrm{~kb} \text { in size } \\
>300 \text { fragments }\end{array}$ & $\begin{array}{l}\text { One or more } \\
\text { fragment }>200 \mathrm{~kb} \\
30-200 \text { fragments }\end{array}$ \\
\hline $\begin{array}{l}\text { AluI } 2 \text { AG/CT } \\
\text { BsshII } 2 \text { G/CGCGC } \\
\text { HaeII } 2 \text { GG/CC } \\
\text { HhaI } 2 \text { GCG/C } \\
\text { Hinfl } 2 \text { G/ANTC } \\
\text { HpaII } 2 \text { C/CGG } \\
\text { MboI } 2 \text { /GATC } \\
\text { MboII } 2 \text { GAAGAN } / \\
\text { NaeI } 2 \text { GCC/GGC } \\
\text { NspII } 2 \text { GNGCN/C } \\
\text { NspIII } 2 \text { C/YCGUG } \\
\text { NspIV } 2 \text { G/GNCC } \\
\text { PalI } 2 \text { GG/CC } \\
\text { TaqI } 2 \text { T/CGA }\end{array}$ & 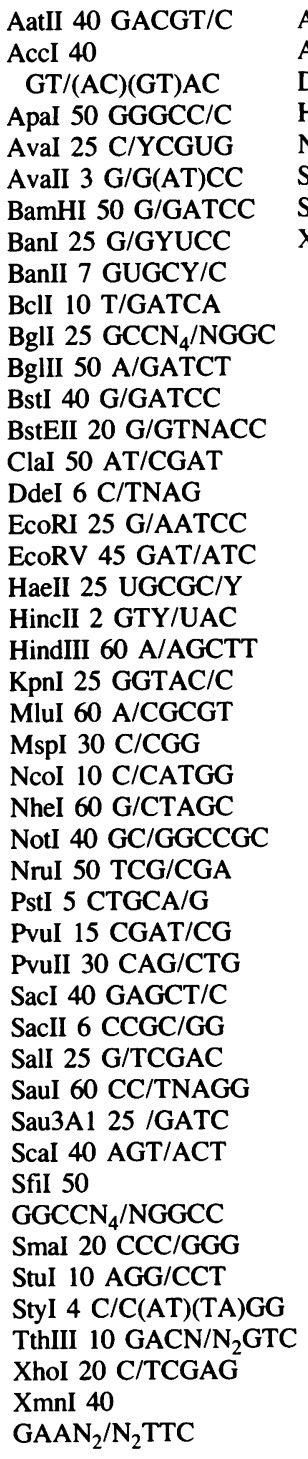 & $\begin{array}{l}\text { AflII } 340 \mathrm{C} / \mathrm{TTAAG} \\
\text { AsnI } 370 \mathrm{ATT} / \mathrm{AAT} \\
\text { DraI } 500 \mathrm{TTT} / \mathrm{AAA} \\
\text { HpaI } 410 \mathrm{GTT} / \mathrm{AAC} \\
\text { NdeI } 300 \mathrm{CA} / \mathrm{TATG} \\
\text { SpeI } 695 \mathrm{~A} / \mathrm{CTAGT} \\
\text { SspI } 200 \mathrm{AAT} / \mathrm{ATT} \\
\text { XbaI270 T/CTAGA }\end{array}$ \\
\hline
\end{tabular}

DNases, and all manipulations were performed under a laminar flow hood.

The presence of plasmids was investigated in samples subjected to pulsed field electrophoresis for $18 \mathrm{hr}$ (60 and 120 second pulses) without restriction cleavage (22).

\section{RESULTS}

A total of 65 restriction enzymes were used to screen for fragments from the Pseudomonas 33468 genome. All 65 restriction enzymes cut the genome into multiple fragments. Only 8 of the 65 enzymes (AflII, AsnI, DraI, HpaI, NdeI, SpeI, SspI and $\mathrm{XbaI}$ ) produced fragments greater than $200 \mathrm{~kb}$ in size. SpeI cut the Pseudomonas genome into less than 35 fragments, while

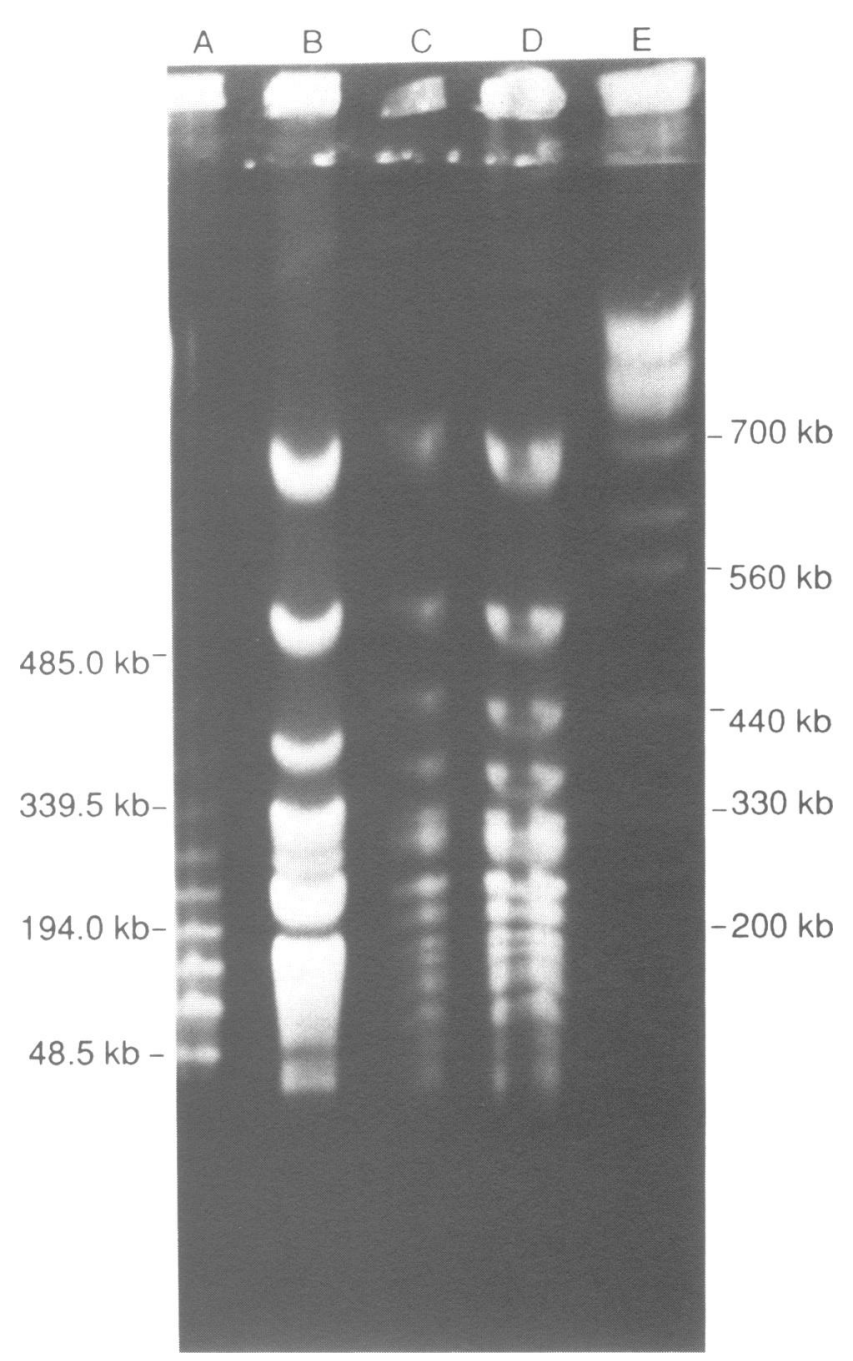

Figure 1. Digestion of Pseudomonas strains with SpeI. Lane A lambda concatemers (48.5 kb monomer), lane B strain 29260 SpeI digest, lane C strain 33467 SpeI digest, lane D strain 33468 SpeI digest, lane E yeast.

the other seven rare cutting enzymes cut it into over 80 fragments each. Table 1 lists the restriction enzymes screened for this study, and the largest fragment detected for each enzyme.

Three tetranucleotide sequences, ATAT, TTAA and CTAG, were extremely rare in Pseudomonas DNA, and each of the 8 rare cutting restriction enzymes contained one of these tetranucleotides in their recognition sequences.

Strains 33467 and 33468 had identical restriction patterns with all restriction enzymes tested (AflII, AsnI, DraI, HpaI and SpeI). The fragments produced by digesting strain 29260 with the same enzymes were markedly different (figures 1-2).

To determine the size of the Pseudomonas genome, restriction fragments resulting from SpeI digestion were compared with standards. Strain 29260 yielded 29 fragments ranging in size from 20 to $720 \mathrm{~kb}$, and strains 33467 and 33468 had 31 identical fragments ranging from 11 to $695 \mathrm{~kb}$. The total size of the Pseudomonas genome was $5573 \mathrm{~kb}$ (29260) and $5407 \mathrm{~kb}(33467$ and 33468) (table 2).

No plasmids were detected in either strain. Since all the 


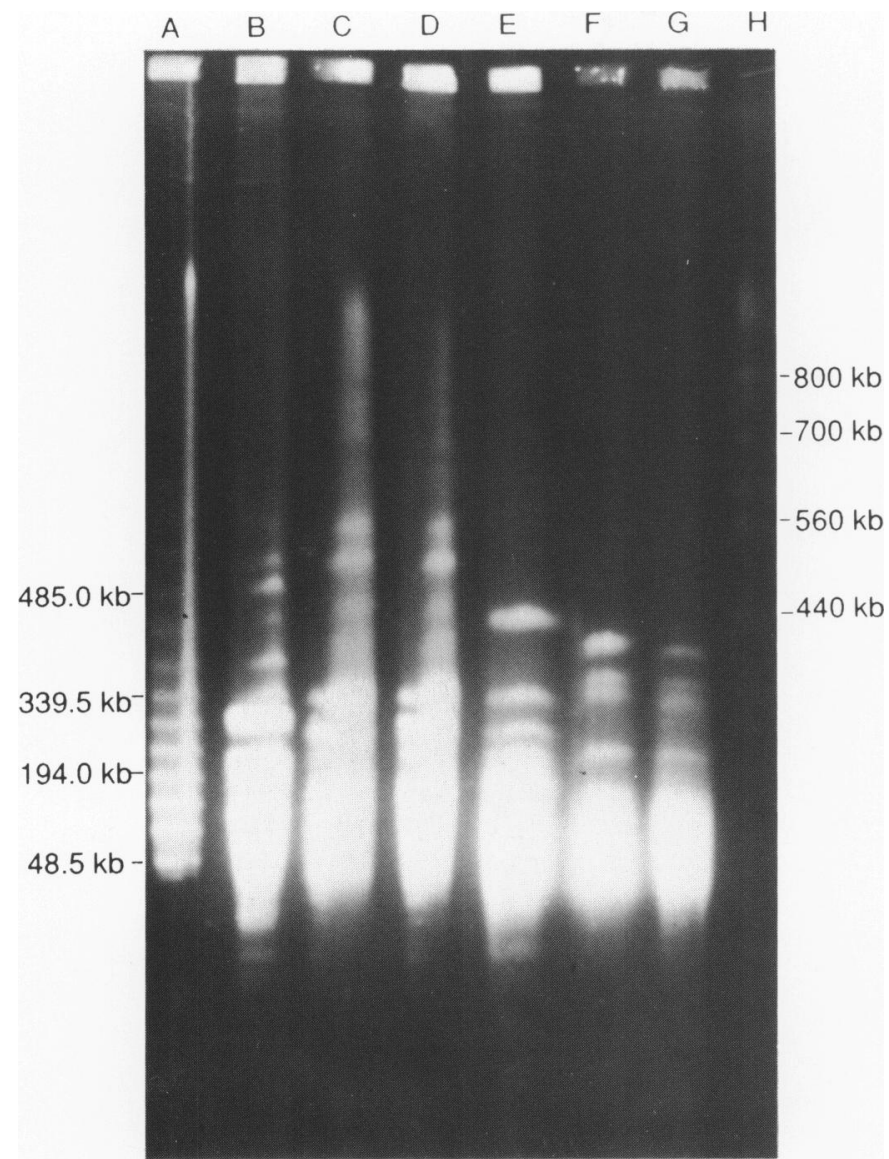

Figure 2. Digestion of Pseudomonas strains with AflII and HpaI. Lane A lambda concatemers ( $48.5 \mathrm{~kb}$ monomer), lane B strain 29260 AflII digest, lane $\mathrm{C}$ strain 33467 AflII digest, lane D strain 33468 AflII digest, lane E strain $29260 \mathrm{HpaI}$ digest, lane F strain $33467 \mathrm{HpaI}$ digest, lane G strain $33468 \mathrm{HpaI}$ digest, lane $\mathrm{H}$ yeast.

bacterial DNA remained in the well during electrophoresis, these results also indicate that the Pseudomonas genome is intact, and that no shearing or degradation of DNA occurred during preparation, storage or electrophoresis.

\section{DISCUSSION}

Estimations of the Pseudomonas genome sizes vary widely. Pemberton estimated the $P$. aeruginosa genome to be $3624 \mathrm{~kb}$ (23), while Bak et al. (24), using renaturation kinetics, obtained a value of $10,440 \mathrm{~kb}$. For other organisms studied by both PFGE and renaturation, the PFGE values tend to be higher than the renaturation values.

Using PFGE electrophoresis we found the Pseudomonas aeruginosa genomes to be $5407 \mathrm{~kb}$ (strains 33467 and 33468) and $5573 \mathrm{~kb}$ (strain 29260). Since strains 33467 and 33468 lack the enzyme indophenol oxidase, the gene for this enzyme may be deleted. Both strains were isolated from sputum of a single patient and have identical fragment patterns. They may represent one strain with a difference in expression of mucoid protein, or one strain may have produced a mutant which coexisted in the sputum and subsequent culture. Strain 29260 is very similar to strains 33467 and 33468 in genome size and number of fragments
Table 2. Restriction fragments from $P$. aeruginosa 33468 and 29260 genomes

\begin{tabular}{|c|c|}
\hline Spe I 29260 & Spe I 33468 \\
\hline 720 & 695 \\
\hline 540 & 500 \\
\hline 410 & 430 \\
\hline 330 & 385 \\
\hline 325 & 325 \\
\hline 305 & 312 \\
\hline 285 & 310 \\
\hline 265 & 265 \\
\hline 260 & 260 \\
\hline 210 & 230 \\
\hline 180 & 220 \\
\hline 170 & 180 \\
\hline 160 & 170 \\
\hline 150 & 160 \\
\hline 140 & 150 \\
\hline 135 & 145 \\
\hline 130 & 105 \\
\hline 120 & 100 \\
\hline 110 & 99 \\
\hline 95 & 70 \\
\hline 90 & 50 \\
\hline 85 & 37 \\
\hline 75 & 36 \\
\hline 70 & 34 \\
\hline 65 & 29 \\
\hline 63 & 24 \\
\hline 40 & 23 \\
\hline 25 & 21 \\
\hline \multirow[t]{3}{*}{20} & 16 \\
\hline & 15 \\
\hline & 11 \\
\hline \multicolumn{2}{|c|}{ Total number of fragments } \\
\hline 29 & 31 \\
\hline \multicolumn{2}{|c|}{ Total kilobase size of genome } \\
\hline 5573 & 5407 \\
\hline
\end{tabular}

and is described as a fairly typical Pseudomonas. We found no plasmids to account for the size difference between strains. The similarity in size and number of fragments of the three genomes, however, supports the ATCC listing that all strains are of the same species.

McClelland et al. (21) calculated trinucleotide frequencies from sequenced Genbank DNA and found the rarest sequences to be CTA/TAG (1.44\%), TAA/TTA $(1.70 \%)$ and ATA/TAT (1.89\%). Our own analysis of the 29 Pseudomonas sequences currently available in Genbank showed the three same rare trinucleotides in the order TAA/TTA $(0.88 \%)$, ATA/TAT (1.11\%) and CTA/TAG (1.29\%). Our experimental data confirms those results, with all 8 rare cutting enzymes recognizing one of these three sequences.

We conclude that the best approach to genomic size studies is to choose restriction endonucleases with recognition sites that contain trinucleotides occurring infrequently in sequenced genomic DNA from the organism. If genomic DNA has not been sequenced, then the restriction enzymes can be selected based on $\mathrm{G}+\mathrm{C}$ content of the organism.

We also conclude that PFGE provides a highly sensitive method for distinguishing different strains of bacteria. The size of the Pseudomonas aeruginosa genome has now been determined, and the SpeI restriction fragments have been identified. The next step in clarifying the gene map of Pseudomonas aeruginosa will be to construct a physical map of the restriction fragments. 


\section{ACKNOWLEDGEMENTS}

This work was supported by the National Institute of Health grants HL-39943 and HL-36538. We thank Dr Ali Azghani for assisting with Pseudomonas culture methods, Dr Gokul Das for technical advice, Dr Lynn Gray for photographs, and Mrs Pat Genoway and Mrs Sara Shepherd for computer progamming.

\section{REFERENCES}

1. Chu,G., Vollrath,D. and Davis,R.W. (1986) Science 234, 1582-1585.

2. McPeek,F.D., Coyle-Morris,J.F. and Gemmil,R.M. (1986) Anal. Biochem. 156, 274-285.

3. Clark,S.M., Lai,E., Birren,B.W. and Hood,L. (1988) Science 241 , 1203-1205

4. Bancroft,I. and Wolk,C.P. (1988) Nucl. Acids Res. 16, 7405-7418.

5. Schwartz,D.C. and Cantor,C.R. (1984) Cell 37, 67-75.

6. Smith,C.L., Matsumoto,T., Niwa,O., Klco,S., Fan,J., Yanagida,M. and Cantor,C.R. (1987) Nucl. Acids Res. 15, 4481-4489.

7. Snell,R.G. and Wilkins,R.J. (1986) Nucl. Acids Res. 14, 4401-4405.

8. Sor,F. (1988) Nucl. Acids Res. 16, 4853-4863.

9. Mortimer,R K. and Schild,D. (1985) Microbiol. Rev. 49, 181-213.

10. Birren,B.W., Lai,E., Clark,S.M., Hood,L. and Simon,M.L. (1988) Nucl. Acids Res. 16, 7563-7582.

11. Smith,C.L., Lawrance,S.K., Gillespie,G.A., Cantor,C.R., Weissman,S.M. and Collins,F.S. (1987) Methods in Enzym. 151, 461-489.

12. Smith,C.L. and Cantor,C.R. (1987) Methods in Enzym. 155, 449-467.

13. Smith,C.L., Econome,J.G., Schutt,A., Klco,S. and Cantor,C.R. (1987) Science 236, 1448-1453.

14. Pyle,L.E., Corcoran,L.N., Cocks,B.G., Bergemann,A.D., Whitley,J.C. and Finch,L.R. (1988) Nucl. Acids Res. 16, 6015-6025.

15. Lee,J.J. and Smith,H.O. (1988) J. Bact. 170, 4402-4405.

16. Kauc,L., Mitchell,M. and Goodgal,S.H. (1989) J. Bact. 171, 2474-2479.

17. Lee,J.J., Smith,H.O. and Redfield,R.J. (1989) J. Bact. 171, 3016-3024.

18. Gardiner,K., Laas,W. and Patterson,D. (1986) Somatic Cell Mol. Genet. 12, $185-195$.

19. Hampton,K.D. and Wasilauskas,B.L. (1979) J. Clin. Micro. 9, 632-634.

20. Liu,P.V. (1973) J. Infect. Dis. 128, 506-513.

21. McClelland,M., Jones,R., Patel,Y. and Nelson,M. (1987) Nucl. Acids Res. 15, 5985-6005.

22. Levene,S.D. and Zimm,B.H. (1987) Proc. Natl. Acad. Sci. USA 84, 4054-4057.

23. Pemberton,J.M. (1974) J. Bact. 119, 748-752.

24. Bak,A.L., Chrisiansen,C. and Stenderup,A. (1970) J. Gen. Micro. 64, 377-380. 